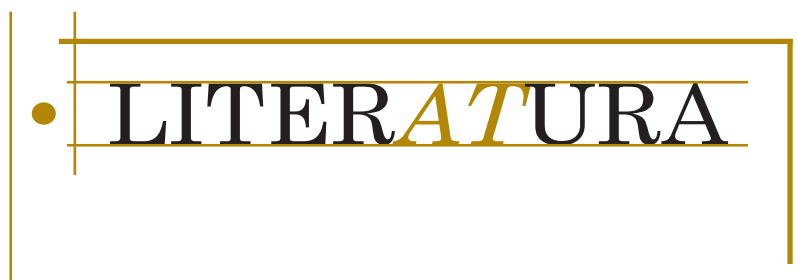




\title{
DROWNING IN A WIDE SARGASSO PATRIARCHY: THE BORDERLAND'S REVISION OF FEMALE PROTOTYPES
}

Davi Silva Gonçalves*

\begin{abstract}
Historical records and interpretations are imperfect and open to the possibility of amending. Through literary analysis, I propose a dialogue between the first and second waves of the feminist movement - in what regards the (re) presentation and voice of different sorts of women (i.e. occupying spaces of diverging subalternity statuses). Hence the specific context of this study: Brontë's novel Jane Eyre (1847) and Rhys' novel Wide Sargasso Sea (1966), focusing specifically on how the character Bertha/Antoinette is given (or not) voice to speak, and wherefrom.
\end{abstract}

Keywords: Jane Eyre. Wide Sargasso Sea. Historical Revision.

Wild tongues can't be tamed, they can only be cut out (ANZALDÚA, 1987, p. 18).

\section{Introduction: "The Paints are also the Picture Itself"}

D earing in mind that, as Schopenhauer (1970, p. 103) had once alerted us, "the word of man is the most durable of all material", it seems of paramount importance for one to tackle written material with caution - both when writing and when interpreting it. Nevertheless, the fact that words consist of the most durable material produced by us does not necessarily imply that what is written is concrete, unchanged, and fixed throughout the passage of time. On the contrary, the word of man is the most durable of all material precisely because it is impalpable - precisely because, as time goes by, we are 
able to understand it differently, to provide it with new meanings that might have never been there beforehand. In this sense, I agree with Foucault (1977, p. 162) when he poses that "the purpose of history is not to discover the roots of our identity, but to commit itself to its transformation". The roots of identity are not available any longer; hence the ambition of cultural studies, which is not to grant us with the lost essences of our ancestors - but to problematise the issue of essence, manifesting the transmutable nature of identity, and exploring such nature as materially as possible. With that taken into account, I get to the problem investigated by this study, which consists of the fact that subaltern women have historically been described as animalised and hypersexualised, as if in need to be "named"/"controlled" - and such notion still survives in the contemporaneity. This is so not simply because of men, or because of women, or because of the West, or because of the white, etc. It is easy to find villains for the suffering of victimised subjects, but it is true that there are many more victims than villains - and that many of these victims are also guided and/or forced to victimise others. In the end, "history is made by men and women, just as it can also be unmade and rewritten, always with various silence and elisions, always with shapes imposed and disfigurements tolerated" (SAID, 1978, p. 72).

History has, therefore, many blanks in need for one to fill in with particular stories - stories silenced and elided due to the imposition of grand narratives (the narratives told and reinforced by hegemonic interests). A revisionist approach to history is thus required, inasmuch as "revisionism refers to any efforts to revise a faulty existing historical record or interpretation" (RICH, 1972, p. 21). Historical records and interpretations are imperfect and open to the possibility of amending, and, following such direction, my research proposes to establish, through literary analysis, a dialogue between the first and second waves of the feminist movement - in what regards the (re)presentation and voice of different sorts of women (i.e. occupying spaces of diverging subalternity statuses). If I am dealing with the issue of historical revisionism, it is essential nonetheless for us to have a definition of its operational condition, in the first place. Still according to Rich (1972, p. 32), such a revision is nothing but the "act of looking back, of seeing with fresh eyes, of entering an old text from a new critical direction - more than a chapter in cultural history: it is an act of survival". For the subaltern woman, historical revision is indeed an act of survival - insomuch as, when one is ignored by credited historical documents, his/her existence is erased; depriving us of our part in history is to divest us from our identities. Hence the specific context of this study: Brontë's novel Jane Eyre (1847) and Rhys' novel Wide Sargasso Sea (1966), focusing specifically on how the character Bertha/Antoinette is given (or not) a voice to speak in these narratives, and wherefrom in terms of discursive positioning. As one could infer, any marginalised voice would generally be with an avid appetite for speaking: but for such a voice to enter the discursive regime and gain a position of privilege there is still much to be done. This is why, when one speaks, this discourse produced must be concerned not only with manifesting well one's opinion and version of events regarding his / herself - but also, and perhaps more importantly, with what concerns surrounding subjects, secondary characters, the "others" of the narrative. The stories we tell and that are the result of our experience become the source of other stories and experiences; in the literary cycle, reality and fiction are in constant dialogue as subjects' identities (subjective or objective) influence 
and interfere with one another. In the words of Wolf (2008, p. 362), "paints are the means of a picture as an end, but the paints are also the picture itself".

Images produced also produce other images; fictional subjects based on concrete ones also become the basis for the characterisation of "real people". The common process of identifying, in identity terms, someone as something is necessarily "the production of an image of identity and the transformation of the subject in assuming that image" (BHABHA, 1994, p. 45). There is no way to dodge such process - all characterisations are naturally based on pre-established relations (on previous assumptions of ready prototypes) - but raising awareness to its existence is an important step for identity prototypes to be altered or (at least) reconsidered. The overall goal of my analysis is, therefore, to problematise unilateral and supposedly universal representations of hegemonic and non-hegemonic women, paying special attention to how literature might serve to reinforce and/or put into question such a representation. If the literary text "both puts down roots in the unity of a context and immediately opens this non-saturable context onto a recontextualization" (DERRIDA, 1992, p. 63), understanding how such recontextualisation occurs and how revisionism might come into play - is fruitful for the problematisation I propose. Conscious that literature thereby enhances the possibilities of identity instead of reducing them (aiming at infinity to the detriment of totality), I herein analyse the development of both novel's protagonists in Jane Eyre (BRONTË, 1847) and Wide Sargasso Sea (RHYS, 1966). My gaze reflects mainly upon the manner how Bertha/Antoinette is represented therein, so as to compare and contrast how the critique on race and gender is articulated. Scavenging an opportunity to emerge as a consistent subject from the slivers of characterisation provided in Jane Eyre (BRONTË, 1847), Antoinette reappears in Rhys' (1966) novel and therefrom new epistemes are provided. That is consistent with Wolf's (2008, p. 74) allegation that "feminists of various persuasions and with remarkably diverse disciplinary backgrounds are debating the rise of gender not so much against an earlier, pre-feminist era, but within feminist theory itself".

My analytical tools that provide the theoretical framework for guiding the analysis consist mainly of the following: Spivak's (1994) critique on the autonomy/ voice of the subaltern; Bhabha's (1994) notion of self and other as indissoluble; Rich's (1972) view on the importance of historical revisionism for subaltern women; Butler's (1990) theory on gender trouble and performance; and Rodríguez' (2010) reflections upon queer identity, sexuality, and (lack of) futurity. Knowledgeable about the fact that "difference has been used to confirm, rather than destabilize, the centrality of received cultural norms" (ÁVILA, 2005, p. 14), I then raise two hypotheses. The first is that Wide Sargasso Sea (RHYS, 1966) demonstrates how, historically, Western civilisation has behaved as if gender constructions and relations existed devoid of any power structure and/or hierarchy, which is far from being the case. The second is that the development of Antoinette might be read as an endeavour to allow the subaltern to speak, providing an extension or, better, a revision of Brontë's narrative as the figure of "the other" is no longer simply gazed upon by the centre. The subaltern is finally put in the spotlight as a source of discursive and epistemological - plus ontological - positionings, which is coherent with Spivak's (1994, p. 87) distinction between the object of investigation and the subject of enunciation. "If the first great wave of the feminist movement in late $19^{\text {th }}$ and early $20^{\text {th }}$ century failed to bring about profound changes in 
gender relations [...]. The binary oppositions that inform most of western cultural practices were never really challenged" (FUNCK, 1998, p. 21). This is why rescuing enunciation is a necessity - binary oppositions are still operational and, as a matter of fact, are the very cornerstone for much of our hegemonic ontologies. One might assume, a priori, that gender relations have nothing to do with literary material - but literature, through alterity, is responsible for establishing innovative archetypes that might never surface from other discursive sources. Otherness is the sine qua non of literature; hence the need for the issue of female identity construction to be addressed - "not simply as a struggle to assert identity but as a struggle to assert difference" (BUTLER, 1993, p. 209).

\section{Discussion: "What I SEe IS NOThing, I WANT What IT Hides"} that

Contemporary approaches on the issue of identity are now marked by the fact

[...] the transverse, transnational, transcultural movements, which were always inscribed in the history of colonisation, have, of course, emerged in new forms to disrupt the settled relations of domination and resistance inscribed in other ways of living" (HALL, 1996, p. 251).

Pre-assigned meanings of domination, resistance, freedom, and autonomy are disrupted by the transverse movements upheld by the subjects who, inscribed in the history of colonisation, are deeply marginalised in the colonial and neocolonial processes permeating the pastoral redimensioning of marginalised regions and peoples. Jane Eyre (BRONTË, 1847, p. 272) is, as the following excerpt suggest, par excellence a token of female hopelessness and rebellion against male authority: "Women suffer from too rigid a restraint, too absolute a stagnation, precisely as men would suffer [...]. It is thoughtless to condemn if they seek to do more or learn more than custom has pronounced necessary for their sex". Moments like these, when Jane manifests her indignation regarding female condition, are recurrent in the narrative; each stage of it is actually an explanation to how she grapples with this condition - transformed from a passionate and motivated child into a calm and composed grown woman. The development of our protagonist is herein very different from the development of Rhys' (1966) Antoinette, as we are "presented to aspects of her life that lead her to loss of self and sanity" (HERISCHIAN, 2012, p. 74). These are two very distinct characters: Jane Eyre is a white, well-fed and educated woman, whose ambition is, in a nutshell, to embark on a professional career just as man could do by that time. Such drive "reflects the struggle of middle-class women to enter the world of their male social equals and prioritises the political forum as the place to promote their interests" (WOLF, 2008, p. 194). Antoinette, Rhys' (1966) protagonist (if we could say so), has much more to fight for - her career is consequently not even considered within the process. If Wide Sargasso Sea (RHYS, 1966) ends with the protagonist committing suicide in a fire she herself provokes, Jane Eyre (BRONTË, 1847, p. 356), finishes much more "comfortably" for the protagonist. Jane finally gets married to the man she loves and bestows readers with the following speech concerning their union: 
No woman was ever nearer to her mate than I am: ever more absolutely bone of his bone, and flesh of his flesh. All my confidence is bestowed on him, all his confidence is devoted to me; we are precisely suited in character-perfect concord is the result.

Romanticised and chauvinistic as it may seem, is important however for one to bear in mind that Brontë's (1847) narrative limitations are a token of the time when it was written. Such was a period when, as Foucault (1990, p. 37) reminds us, gender and sexuality (male and female) should be tackled only as "to ensure population, to reproduce labour capacity, to perpetuate the form of social relation, to constitute a sexuality that is economically useful and politically conservative". Consciously or not (probably not), Jane Eyre (BRONTË, 1847) therefore also informs readers about the historical moment wherefrom it was conceived - an information that consists in what Althusser (1971, p. 205) regards as the disarray of a text: "The concealed order of the work is thus less significant than its real determinate disorder (its disarray)". Apropos, Funck (1998, p. 22) reminds us that, within such determinate disorder, subject positions are neither totally determined nor freely chosen: "Different subject positions are proposed and the individual may, depending on his or her power to choose, take up the positions offered". There are levels of freedom and levels of autonomy, and when I look only at what concerns me, those who are in a worse position are forgotten - even though they might not have the same opportunity to claim their own autonomy as well. All women are still, to a less or more considerable extent, marginalised by a hegemonic narrative based upon the sovereignty of what is male, white, Eurocentric, and heterosexual. Displacements occurring within this complex structure are, nonetheless, "more varying and contradictory than it is suggested by its protagonists." (HALL, 1996, p. 97). Protagonists determine the centre (a position they naturally occupy) and marginalise the rest - by vitiating the needs, values, and epistemes of the "others" or, more often, by exoticising and romanticising them. Rhys' (1966, p. 54) characterisation of Rochester evinces, through his voice, such common procedure. Getting to Jamaica, where he is about to meet his future wife (Antoinette), he seems to be mesmerised by the place: "wild, untouched, above all untouched, with an alien, disturbing, secret loveliness. It kept its secret, I'd find myself thinking. What I see is nothing - I want what it hides". Rochester's admiration for the seemingly pristine landscape of Jamaica is about to be transformed into his will to domesticate and tame what belongs to it - and that he wants for himself. His discourse, here, manifests rather clearly the configuration of hegemonic pastoralism - the idea that what is different from Western tradition is already lost and about to be adapted (what is untouched, in this sense, would be waiting to be touched).

That is what Lyotard $(1979$, p. 81$)$ names as the grand narratives: "the pursuit of such grand narratives is seen as a manifestation of the will to power [...], but the postmodern repudiation of Enlightenment makes it possible to share collectively the nostalgia for the unattainable". Rochester is impressed by the place, but withal incapable of trying to understand it - his agenda pre-empts a possibly authentic experience therein, and his wonder is thus turned into a severe disillusionment as soon as he learns the exotic does not survive very long in the real world. His hidden marriage to Antoinette (whose name he changes to Bertha) represents British domination over the colony (and its subjects); and so does his rage and disgust 
concerning her: "I hate her [...] for she belonged to the magic and the loveliness. She had left me thirsty and all my life would be thirst and longing for what I had lost before I found it" (RHYS, 1966, p. 111). The term "Pastoralism" is brought henceforward as problematised by Leo Marx (1964). In his view, pastoralism is related to the idea of a supposedly virgin continent-as if the natives who were here before the arrival of the Europeans were just a picayune detail mixed with the fauna and flora enveloped by the mysticism of their exotic milieu-deserves to be reconsidered. This opportunity for the new beginning of Western civilisation, whereby humankind would be able to give life to their poetic fantasy and environmental romanticism, is also debunked by Carolyn Merchant (2003) and Mary Louise Pratt (1992). Pastoralism as an ideological stance has been ultimately removed from its traditional literary context and brought therefrom to the ideological and political construction of nature as belonging to a transcendental scope. The classic figure of the good shepherd resurrects with a clear agenda; taken from the industrial and corrupted European existence, he/she believes in the chance of a new beginning in the New World. Alpers (1982, p. 449) discusses about the interaction between landscape and shepherd. In his view, many interpreters of pastoral think of landscape as representative anecdote, but this view of pastoral comes from Romantic poetry and aesthetics, "which give a privileged status to individual sensibility and spiritual experience; it seems to make far more sense to say that the representative anecdote of pastoral is the lives of shepherds". The pastoral anecdote has granted the world with a vast array of images that, regardless of our impressions and/or opinions, are already there - there is no way to start over with a clean slate -, and revising history is thus about providing documents with new versions of events, as what has been narrated can no longer be erased or simply abandoned.

The image Brontë (1847, p. 250) conveys of this animalised and unknown woman described by Jane Eyre - who happens to be married to the man she falls in love with - is one of these identities that cannot be expunged (only rewritten). This is "a woman, tall and large [...]; a discoloured face, a savage face. I wish I could forget the roll of the red eyes. The lips were swelled and dark [...]. Shall I tell you of what it reminded me? A vampire". Like herself, and even though many of her attributes are amiss (her voice, name, origin, story, condition, etc.), this monstrous being is a woman - and in an even more peripheral condition if compared to Brontë's (1847) protagonist. Descriptions are, apropos, growingly creepy: "in the deep shade, at the farther end of the room, a figure ran backwards and forwards. What it was, whether beast or human being, one could not, at first sight tell; it snatched and growled like some strange wild animal" (BRONTË, 1847, p. 327). Such characterisation of this Jamaican woman as a strange wild animal implies Bhabha (1994, p. 44) is right when he suggests the image of the self is tethered to, not confronted by, its dark reflection - the shadow of the colonised, splitting one's presence and distorting one's outline and who "disturbs and divides the very time of his being". Characterisations like the one set forward by Jane Eyre "elides the need to confront what one is through a more extensive questioning of the entanglements of one's history within History - by historicising the present and one's place within it" (WOLF, 2008, p. 6). One's history within History is indeed an issue of paramount importance, inasmuch as notwithstanding Jane Eyre's ability to end up rather well as she is able to depart from a hard and challenging past to a placid and comfy future, she is granted with the tools and 
opportunities for such path to be traced. What one cannot forget nonetheless is that such "futurity has never been given to [...] marginalized communities that live under the violence of social erasure" (RODRÍGUEZ, 2010, p. 331). Rochester's first wife, locked within the attic, is one of these subjects who suffer the violence of social erasure - her monstrous condition is explained by Rhys' (1966) narrative of revision, even though its motives are never addressed by Brontë (1847).

The idea of her "vampirism" is, on the contrary, reinforced by Richard Mason (Bertha's brother), whose description of his sister is alongside Jane's animalisation of her: "She bit me. She worried me like a tigress, when Rochester got the knife from her... She sucked the blood: she said she'd drain my heart" (BRONTË, 1847, p. 340). It is as if this woman lacked every moral valence, for no consistent reason; behaving like an animal, her own history would only be told when Rhys (1966) decides to revise it, writing from a postcolonial perspective. Regardless of our mobility, we are also sessile animals to the extent that our personality, behaviour, and characteristics depend upon and are directly affected by our history - we are forged by our historical conditions, notwithstanding the fluidity we allegedly attach to our purportedly self-directed beings. Given such picture, "it is essential for the postcolonial subject to think the present historically and summon the return of a seemingly eliminated space" (HALL, 1996, p. 8). That is precisely what Rhys' (1966) seems to be doing in her novel - taking advantage on the fact that "in creating the character of Bertha Mason, Brontë unknowingly allowed for a whole other story and description of female experience to be told" (HERISCHIAN, 2012, p. 72). There is not one single female experience that summarise the condition of all women - there are only female experiences, in the plural form, which all highlight diverging views and forms of subalternisation, triggering retextualisations of female conditions and conditionings and attempting at recovering the most varied levels of independence from social restraints. If the task of historical documents, written and sanctioned by hegemonic master narratives, is to remove the history of the "other", the task of literature is precisely to "document the embarrassing presence of this other in cultural places where one least expects to find it" (MORRISON, 1996, p. 14). In her hybrid condition as a mixture between whites and blacks, Antoinette is finally given voice to tell readers about the hostility she found in both these worlds - her belonginglessness results in her spaceless and timeless condition, as a subject without a nation, a story, and, consequently, an identity. Concerning her black neighbours, she says, "They hated us. They called us white cockroaches. Let sleeping dogs lie. One day a little girl followed me singing, 'Go away white cockroach, go away, go away"' (RHYS, 1966, p. 32).

With the death of Antoinette's father, the former slave owner Mr. Cosway, her family is not only ruined, but exposed to the open threats and abuse of the community - who disregard them completely, as do the Europeans who visit Jamaica to do business or to get married (as if there were any difference between them). Her situation is analogous to Anzaldúa's (1987, p. 203) elaboration upon the condition of the mestiza living in the borderlands: "As a mestiza I have no country, my homeland cast me out; yet all countries are mine because I am every woman. I have no race, my own people disclaim me; but I am all races because there is the queer of me in all races." Precisely, occupying no place in particular is synonymic with occupying a little bit of every place the circumscribes nowhere - the fluidity of the postcolonial subject means $\mathrm{s} /$ he fits everywhere else, as the 
binarism of the colonised vs. coloniser is no longer enough (it has actually never been) to outline his/her characterisation and development. Anzaldúa's (1987) notion of the borderlands than dialogues with Bhabha's (1994, p. 25) view on the hybridity of the postcolonial experience. "Liberated from the constraints of a binary chimera, the post-colonial subject is now seen to occupy a space which is neither the one nor the other, but a new space of translation which results in the heterogeneous hybrid subject". Paring the monstrous exaggerations of Antoinette's characterisation in Jane Eyre (BRONTË, 1847), Rhys' (1966) takes up her flawed descriptions and brazes them out - shaping a complete distinct narrative, but one that is capable of telling another story about the postcolonial without necessarily romanticising it. Antoinette, therefore, is not therein built as a perfect character; on the contrary, she makes many mistakes and exhibits a consistent prejudice and bias concerning other subjects (perhaps as a response to the prejudice and bias she herself suffers from). One of the moments when that can be spotted is in the following: "How can she know the best thing for me to do, this ignorant, obstinate, old negro woman, who is not certain if there is such a place as England?" (RHYS, 1966, p. 32). In this excerpt, Antoinette unveils her own racism when she talking to her servant Christophine. Even though in other moments she demonstrates sympathy and identification regarding black subjects (with whom she identifies to some extent) she still reveals to have racist opinions and attitudes nurturing the idea that blacks are inferior - although she is, herself, partially black.

Therefore, ascribing her supposed ignorance to her race, Antoinette's prejudice towards Christophine prevents readers from romanticising the character - as in many occasions, her position is in consonance with hegemonic interests and she endorses the master narrative of Eurocentric thinking. Through an admixture of facts and fiction, Rhys (1966) discusses the functioning of Imperialism epistemologically and ontologically - and, in the previous excerpt, another important artefact of her narrative surfaces in what concerns both these issues: that of sanctioned vs. unacceptable ignorance. Spivak (1994, p. 310) poses that we are educated through a process whereby "we learn to avow and remember certain knowledges and devalue and forget others; within such an interlocking mechanism for the production of knowledges and sanctioned ignorances our subjectivities are forged". When Antoinette criticises Christophine because she is ignorant about the existence of England, she overlooks the fact that many English citizens might be actually also ignorant about the existence of Jamaica - the latter, however, being more acceptable than the former. Those who are unaware of the existence of central nations fail to fit in the master narrative of hegemonic history (whose focus is precisely directed to such places); even though one might be deeply informed about other places, other realities, other stories, and other epistemological environments, such "success" means nothing whatsoever - the information they know is completely innocuous. Spivak (1994, p. 308) also addresses this dichotomy of success vs. failure as articulated by Antoinette's speech regarding Christophine, posing that one "cannot afford to ignore how conceptions of failure are tied up with preconceived and dominant criteria of success". This contradiction is also evinced in the letter Daniel Cosway (a creole man living with a British master) sends to Rochester. Thereby, the former attempts at providing the latter with evidence that he is a clever and educated man, even though his racial condition prevents him from becoming as intelligent as any white person could be. "The 
good man in Barbados teach me more, he give me books, he tell me read the Bible every day and I pick up knowledge without effort. He is surprise how quick I am. Still I remain an ignorant man" (RHYS, 1966, p. 17). This excerpt exposes the dubious logic of race logic - as even if he studied as much as the whites tell him he should, Daniel could never duck his supposed (and inexorable) racial inferiority. A conclusion whereto we might get from the analysis of both my objects is that, even though responding to the interests of hegemony might be sometimes fruitful and effective, "a better response to being the hybrid subjects of a relation of cultural difference is not to lose sight of the subalternisations. That is, not to speak of sanctioned ignorances - that have maintained the authority of the West" (BHABHA, 1994, p. 18).

\section{Final Remarks: "There is Always the Other Side"}

Eagleton (2010, p. 169) writes that "there is, in fact, no need to drag politics into literary theory: it has been there from the beginning". This is why, to talk about literature, is also to talk about politics; and there is no way for one to understand and analyse the former without taking the latter into account. My analysis of Jane Eyre (BRONTË, 1847) and Wide Sargasso Sea (RHYS, 1966) could never occur without a political discussion; without one's raising awareness to the fact that there is no division between the sexual and the political characterisation of subjects emerging therefrom. In the end, "sexual politics is more political than sexual - and sexual liberation can only occur as part of a general human liberation" (FUNCK, 1998, p. 74). It is precisely towards this general human liberation that literature might guide us, as I hope to have demonstrated. Female characters, as developed in both narratives, expose the layers of subalternisation that cover up the core of the grand narratives told by hegemony; addressing such characters and gazing upon the disarray of their construction is one of our only opportunities to set forward less detrimental contributions for the discursive regimes of our tradition. When reality forgets about us, only fiction might save us from ourselves. Within such framing, and as in Rhys' (1966) appropriation of Brontë's (1847) descriptions of Antoinette, there is a great difference between telling one's own story and having someone to talk about the story about another person. That is, the issue of perspective plays a significant role: appropriating the other is effective only if the purpose is to credit the identity of the self. There are, thus, two poles technically (but only technically) apart: "the sovereign subject (who speaks) over the other (who remains unheard). The latter is re-produced as an object of investigation rather than a subject of enunciation, a field of investment rather than an investor of history" (SPIVAK, 1994, p. 87). Analysing the construction of a character whose identity is provided as a given in Brontë's (1847) narrative, is therefore precisely the path chosen by Rhys (1966) for the object of investigation to be ultimately turned into the subject of enunciation. As Rhys (1966, p. 82) herself alerts us, "there is always the other side". There is indeed always the other side, even for that monstrous senseless character whose situation, in the end, has an explanation - as every reaction caused by a previous action (and which is, in this case, no longer left aside).

Rhys (1966) takes Eco's (1984, p. 61) assertion rather seriously when he claims that "the author offers the interpreter, the performer, the addressee a work to be 
completed". Provided with scraps of a character's identity, she builds a brand new story to reclaim the subaltern an opportunity to position him/herself and set forward another perspective on events (and on his/her own characterisation). The significance of Antoinette's redemption is unquestionable precisely given her primary condition; "because subaltern historiographies might raise many questions, the subaltern cannot speak" (SPIVAK, 1994, p. 286). Hence the advent of literature as a place of transformation; my objects are a manifestation of the silence forced upon the lives of peripheral agents who try to evade passivity and to build, out of nothing, some level of agency. Cultural identity is moulded, through literature, as an "uncomfortable, disturbing practice of survival and supplementarity between art and politics, past and present, the public and the private - as its resplendent being is a moment of enlightenment or liberation" (BHABHA, 1994, p. 175). Jane Eyre (BRONTË, 1847) and Wide Sargasso Sea (RHYS, 1966) shall not be compared for one to judge their values as "better" or "worse"; separated by more than half a century, these narratives have different focuses and agendas, and are both grappling with distinct sorts of marginalisation that women have suffered (and have been suffering). Literature, for both authors, might have served as unsurpassed channel for historical revision and compensation, as Anzaldúa's (1987, p. 48) explanation - regarding the reason why she is compelled - to write suggests: "Because the world I create in the writing compensates for what the real world does not give me [...]. I write because I'm scared of writing, but I'm more scared of not writing". Scared of writing, but more scared of not writing, words are a way out; a chance for the postcolonial and queer perspectives shared by subalternity to materialise and to put into question the assimilation of the other carried out by the self. In what regards female identity, notwithstanding our common alienation concerning such fact, it also behoves literature "to find ways of creating gender trouble, ways of disrupting the connections that bind sex, gender, and desire into a natural and universal order" (BUTLER, 1990, p. 148).

My analysis - focusing on the historical revisionism occurring in Wide Sargasso Sea (RHYS, 1966) and its appropriation and transformation of epistemes granted by Jane Eyre (BRONTË, 1847) - then puts such universal order into question, as well as the fixity and rigidity of the values foundational to the master narrative of hegemony. Brontë's (1847) novel is a classic; and, as a classic, it is fluid and amenable to be read and reread differently given subjects, time, and space constraints. Thence the immortality of the canon: it only survives because it is never the same. Such approach, that aids my reading of the chosen objects of research, is a contribution of cultural studies, which have "relocated canonical literature in the context of the broader field of texts and forms of writing which it excludes. In the process, the canon itself has been extended and transformed" (WOLF, 2008, p. 164). By extending and transforming the canon, Rhys' (1966) story, alongside her reading of Brontë's (1847) story, reminds us that there is still much to change - the revolution of the subaltern is still distant from reaching its climax. One thing is nonetheless certain, at this point: the fact that it would be better "if feminists did without foundational categories - for, rather than being the conditions of possibility for our politics, this foundationalism is that it presumes, fixes, and constrains the very 'subjects' that it hopes to represent and liberate" (BUTLER, 1990, p. 147). The queer and postcolonial experience of those subaltern subjects living (or, better, surviving) in the borderlands shall no longer 
been set aside; and it is not because the borderland is a synonym for the absence of a single place that we should not map it conceptually. Liquefied identities, after all, might end up being much more rewarding than concrete and pre-established ones. That Wide Sargasso Sea (RHYS, 1966) teaches us with unparalleled excellence as thereby the story "revises the figure of the mad Creole into that of a lovely, unnameable self [...] forever out of reach, somewhere in uncharted territory" (MAUREL, 2009, p. 160). There are still many subjects living in uncharted territories, out of reach, waiting for someone to listen to them. As implied by my objects, the subaltern, it seems, is not keen to be simply included within the grand narratives of history - conscious that their survival depend on it, those in the borderlands know there is only one way for such inclusion to effectively occur: through historical revision, nothing more, nothing less.

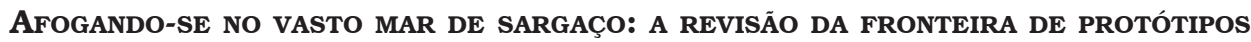 FEMINISTAS}

Resumo: Relatos e interpretações históricas são imperfeitos e estão abertos para a possibilidade de ajustes. Por meio da análise literária, proponho um diálogo entre a primeira e a segunda onda do movimento feminista - naquilo que concerne a (re)presentação da voz de mulheres distintas (ocupando espaços de divergente subalternidade). Daí o contexto específico deste estudo: o romance Jane Eyre (BRONTË, 1847) e Wide Sargasso Sea (RHYS, 1966), com enfoque específico na forma como a personagem Bertha/Antoinette é munida (ou não) de voz para se manifestar, e de que lugar.

Palavras-chave: Jane Eyre. Wide Sargasso Sea. Revisionismo Histórico.

\section{REFERENCES}

ALPERS, P. What is Pastoral? Critical Inquiry, v. 8, n. 3, p. 437-460, 1982.

ALTHUSSER, L. Lenin and Philosophy. London: Monthly Review Press, 1971.

ANZALDÚA, G. Borderlands/La Frontera: The New Mestiza. San Francisco: Aunt Lute Books, 1987.

ÁVILA, E. Diversity and/or Difference. Iha do Desterro, Florianópolis, v. 4, n. 48, p. 9-39, 2005.

BHABHA, H. The Location of Culture. London: Routledge Classics, 1994.

BRONTË, C. Jane Eyre. London: Norton Anthology of English Literature, 1847.

BUTLER, J. Gender Trouble: Feminism and the Subversion of Identity. London: Routledge, 1990.

BUTLER, J. Bodies That Matter. On the Discursive Limits of Sex. London: Routledge, 1993.

DERRIDA, J. Acts of Literature. London: Routledge, 1992.

EAGLETON, T. Literary Theory: An Introduction. London: Blackwell Publishing, 2010. 
ECO, U. The Role of the Reader: Explorations in the Semiotics of Texts. Bloomington: Indiana University Press, 1984.

FOUCAULT, M. Untying the Text: A Post-Structuralist Reader. London: Routledge \& Kegan Paul, 1977.

FOUCAULT, M. The History of Sexuality. London: Penguin, 1990.

FUNCK, S. B. The impact of Gender on Genre: Feminist Literary Utopias in the 1970s. Florianópolis: PPGI, 1998.

HALL, S. The Postcolonial Question. London: Routledge, 1996.

HERISCHIAN, N. Jean Rhys's Wide Sargasso Sea as a Hypertext of Charlotte Brontë's Jane Eyre: A Postmodern Perspective. International Journal of Applied Linguistics \& English Literature, v. 1, n. 6, p. 67-85, 2012.

LYOTARD, J.-F. The Postmodern Condition. Manchester: Manchester University Press, 1979.

MAUREL, S. The Other Stage: from Jane Eyre to Wide Sargasso Sea. Cambridge: Brontë Studies, 2009.

MARX, L. The Machine in the Garden: Technology and the Pastoral Ideal in America. New York: Oxford UP, 1964.

MERCHANT, C. Reinventing Eden: The Fate of Nature in Western Culture. New York: Routledge, 2003.

MORRISON, T. Beloved. London: Vintage, 1996.

PRATT, M. L. Imperial Eyes: Travel Writing and Transculturation. London: Routledge, 1992.

RHYS, J. Wide Sargasso Sea. London: Norton Paperback, 1966.

RICH, A. When We Dead Awaken: Writing as Re-Vision. College English, v. 34, n. 1, p. 18-30, Oct. 1972.

RODRÍGUEZ, J. M. Queer Sociality and other Sexual Fantasies. Lecture at Center for Study of Sexual Cultures. February 8, 2010, Berkeley, University of California. p. 331-348.

SAID, E. W. Orientalism. New York: Random House Inc., 1978.

SCHOPENHAUER, A. The Horrors and Absurdities of Religion. London: Penguin Books, 1970.

SPIVAK, G. Can the Subaltern Speak? In: MORRIS, Rosalind. Can the Subaltern Speak?: Reflections on the History of an Idea. New York: Columbia University Press, 1994. p. 21-78.

WOLF, C. The Cambridge History of Literary Criticism: Twentieth-Century Historical, Philosophical and Psychological Perspectives. Cambridge: Cambridge University Press, 2008.

Recebido em maio de 2016. Aprovado em junho de 2017. 